\title{
Characteristics of Shari'ah Governance and Incidence of Charity: A case of Pakistan
}

\author{
Mohammad Ayaz, Noman Arshed, Ikram ul Haq ${ }^{3}$ \\ ${ }^{1,2}$ University of Management and Technology, Lahore Pakistan \\ ${ }^{3}$ Riphah International University, Lahore Pakistan
}

\begin{abstract}
There are several studies which have evidenced the role of Shari'ah governance on the profitability of Islamic banks for different countries in different data setup. The main purpose of Shari'ah governance is derived from the concept of corporate governance to avoid any non-compliant transactions and book charity against any non- compliant income. There are two kinds of Shari'ah supervisory boards. First is the proactive type that follows the rule of 'Hisba' which restricts any non-compliant transaction before it happens. The second type is reactive which detects and reacts to the non-compliant transactions following the Islamic legal system when they happen. The first type would conclude to a reduction in the incidence of charity transactions. In contrast, the second type would conclude to increase in the incidence of charity transaction. The objective of this study is to explore whether the Shari'ah governance of Islamic banks of Pakistan is jointly proactive or reactive. This study is deductive and uses quantitative methods. This study builds an unbalanced panel data of full-fledged Islamic banks of Pakistan using the available data from financial statements. This study is one of its kinds to see the nature of Shari'ah governance based on empirical patterns using Panel FGLS model. The results show that board size, board expertise, and reputation are the reactive factors while the others are proactive factors.
\end{abstract}

Keywords: Shari'ah Supervisory Board, Panel Data Analysis, Shari'ah Disclosure, Shari'ah Controls.

\section{Introduction}

Currently, the Islamic financial system has spread its network to about 70 countries which include non-Muslim nations too. The major difference of the Islamic financial system and the conventional counterpart is that the former 
requires the divine regulatory framework known as Shari'ah governance framework (Al-Qur'an 3:191; Hassan, 2013). This Shari'ah framework, like a standard corporate governance framework, provides complete guidelines of Islam which include the dealing businesses, documenting contracts, business ethics, disclosure and transparency (Abu-Tapanjeh, 2009). The significant dimensions of Shari'ah framework intervention include: (1) business ethics which means that according to Islam, the quality of deeds has a higher rank (Al Qur'an, 6:132) (2) Decision making which means that it is the responsibility of the bank and the clients to follow Islamic law in every decision (Al Qur'an 3:159, 42:38) (3) Disclosure and Transparency which means they have to be transparent in their transactions and ensure payment of Zakat, and (4) Book-keeping which means that the bank has to record all the transaction to the fullest possible details, which will ensure a high level of moral conduct, fair and honest means of financial practice (Al Qur'an 2:282-283, 21:47).

\subsection{Importance of Shari'ah Governance}

Shari'ah Supervisory Board (SSB), constituted under the Shari'ah governance framework, deals with the Islamic bank's internal and external arrangements and transactions. It ensures a strict adherence to the Shari'ah to increase the trust of Muslim customers and investors, which has an immediate effect on the stability of Islamic financial system (Grais \& Pellegrini, 2006) and earning of Islamic banks (Hanif \& Arshed, 2016). SSB members contribute to clarifying every financial transaction for its compliance with Shari'ah principles (Haqqi, 2014). The criteria for the selection of SSB require a few essential qualifications like knowledge of Islamic studies and Fiqh. For the case of Pakistan, one must have at least 5 years of experience in order to be fit for SSB's membership. The tenure specified for the SSB's members is 3 years, and a minimum of 3 members are required (SBP, 2018).

The major function of the Shari'ah governance is to ensure compliance with Shari'ah rules and principles. For this, any non- compliant income must be avoided and removed from the earning of the Islamic banks. This separated haram (prohibited) income is collected in a pool which is extended to charity (Ginena, 2014). The precedence of such activities is already mentioned in $\mathrm{Al}$ Qur'an and Sunnah. For example, if a person has missed any fast in the month of Ramadhan, then he must complete the count of obligatory fast in any other day (Sahih Al Bukhari, Book 18 Hadith 681), or in another case 'if a person repents in the form of charity' (Al Qur'an 9:104). The charity can be from two sources namely (1) making investments in and extending financing to partially prohibited 
avenues and (2) receiving penalty amounts as a result of delay in payments of installments by the clients (Yaakub, 2014; AAOIFI, 2015). Figure 1 shows the line graph of the annual average of charity paid in natural log form. It shows here that with the passage of time, the Shari'ah governance framework is improving in terms of closing doors on the existing forms of non- compliant incomes and leading to lower and lower charity paid. This reduction in charity collection indicates that generally, Shari'ah governance is following the rule of 'hisba'. According to Al-Qur'an, 'They believe in Allah and the Last Day, and enjoin what is right and forbid what is wrong and hasten to good deeds. And those are among the righteous." Al-Qur'an (3:114). Under the principle of hisba, before happening of any wrong, the authority-holder monitors and supervises the public by enjoining them to do the right and forbids them from doing wrongs. Related to this, there is a proper legal system of Islam, which comes in to play after a wrong doer violates the rules and principles of Islamic law in which case justice is made. These two rules are also applicable to companies (Iqbal \& Mirakhor, 2004). Hence companies (including banks) should also be monitored and supervised to stop them from entering into any non-compliant transactions and to transfer the no ncompliant earnings to charity accounts. Here the role of SSB is expected to be pro-active as well as reactive.

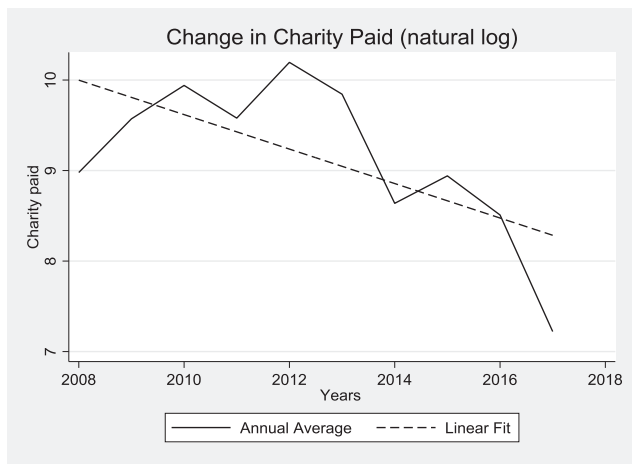

Figure 1.1: Empirical Incidence of Overall Charity Paid by Islamic Banks in Pakistan

\subsection{Shari'ah Governance and Performance}

Zain and Shafii (2018) compiled the previous studies in which they assessed the effect of Shari'ah governance on the performance of the bank. Few of the prominent channels are discussed here. First is that the Shari'ah governance increases customer confidence which leads to an increase in stability (Alnaseer \& 
Muhammad, 2012). Shari'ah governance helps in providing barriers and conflicts within Islamic principles (Garas \& Pierce, 2009). Based on this, studies by (Mollah \& Zaman, 2015; Musibah, 2014; Hanif \& Arshed, 2016) concluded that Shari'ah supervisory committee has a positive effect on firms' performance. Shari'ah audit provides public assurance of the procedures, products, and services of Islamic banks (Chik, 2011). Frequent Shari'ah audit helps the banks to oversee their operations to gradually add value to the business through systematic risk management (Awdat, 2015; Alaswad \& Stanisi, 2016). Lastly, Shari'ah review helps in reviewing the process according to the guideline provided by the Shari'ah supervisory board (Bahari \& Baharudin, 2016). This process helps in mitigating any Shari'ah non-compliance risk and uncertainty (Mansoori, 2011).

A study by Hassan, Rizwan \& Sohail (2017) estimated the effect of Shari'ah governance via indicators like Shari'ah Advisory Board (SAB)'s size and assessed it against the CAMELs based performance indicators. According to the study, SAB only has a significant positive effect on ROE and Cash Ratio for the case of Pakistan.

On the contrary, a study by Nawaz (2017) compared before and after financial crises market performance of banks and the role of Shari'ah Supervisory Board (SSB). This study concludes that since SSB increase the administrative expense, hence it leads to a decrease in performance.

Previous studies have extensively assessed the role of Shari'ah governance with the financial or non-financial performance of Islamic banks. A study by Ayaz et al. (2020) discussed the composition of charity disbursement for the case of Islamic banks of Pakistan. However, there is a dearth of studies which have assessed the nature of Shari'ah Governance in terms of its functionality. This functionality includes cleaning the non-compliant financial transactions using penalizing the non- compliant incomes and extending it as a charity.

The question that is to be answered is that why there is a need of decrease in the charity paid by the Islamic banks when they are socially beneficial? Here we can see that most of the charity is disbursed in Social section specifically heath (Ayaz et al., 2020). To answer this, we must explore the source of this charity; bank is paying this charity when any agreement is declared void according to the Shari'ah rule. Hence increase in the charity paid means that the bank is frequently experiencing invalidation of the agreements which render uncertainty in the documentation and processes of agreement formulation and controls of Islamic banks. The doors of voiding of agreements must be closed; the controls 
must be strict in the matters of halal and haram. The experience of the Shari'ah board must be the source of this closure. This will ensure smooth completion of Shari'ah compliant transactions (Alam et al., 2019). Observing figure 2, Albaraka Islamic bank and $\mathrm{MCB}$ Islamic are experiencing stable / slight increase in the pattern of charity paid while other banks are showing decrease in the patterns of charity disbursements. In 2018, Meezan bank being the biggest Islamic bank has paid charity lower than Al Baraka Bank and Bank Islami, indicating proactive nature (Ayaz et al., 2020).



Figure 1.2: Empirical Incidence of Charity Paid by Islamic Banks in Pakistan

\subsection{Objectives of the Study}

Based on the gap at hand, the objective set by this study is to explore the effects of Shari'ah Governance characteristics of Islamic banks of Pakistan. This study tests functionality in terms of its ability to detect non-compliant income and deduct charity from the bank's income. Whereby, the role of an increase in the quality of Shari'ah governance on the incidence of charity is un-explored.

\section{Literature Review}

Islamic finance is evolving and because of globalization, more and more transactions are happening with non-Islamic banks and countries. Here, scholars have devised to create a charity pool. All earnings from previously or recently known non-compliant means can be kept in this pool with the intentions to purify the remaining Shari'ah compliant income (Ginena, 2014). This setup is made mandatory by most of the Islamic banking systems. For the case of Pakistan, State Bank of Pakistan (SBP) has regulated that the Islamic banks cannot use the charity account for personal purposes (SBP, 2008). Further Islamic banks in Pakistan need to disclose full details of the charity fund, and the amount collected must be spent in the same accounting year (SBP, 2008). 
Yaakub (2014) concluded that Islamic banking in Malaysia has been experiencing late payment and default issues. This is because customers are not allowed to be charged with interest (riba) as opposed to the practices in conventional banking. To mitigate these issues, the Shari'ah Advisory Council of Bank Negara Malaysia has enforced $t a^{\prime} w i d h$ and gharamah as regulatory alternatives. Practically, $t a^{\prime}$ widh and gharamah were imposed on the defaulting customers who fail to meet their obligation to pay their financing based on several conditions.

Yaakub et al. (2013) discussed that the mechanism of ta'widh implementation is different from the proportional penalty charged in conventional banks, which is riba'. The imposition of ta'widh and gharamah by Bank Negara may help Islamic banks in Malaysia to mitigate default payment risk as well as enable Islamic banks to compete with conventional banks. Zulkipli (2019) studied that the mechanism of ta'widh and gharamah that is currently implemented is different from any percentage-based penalty charged in conventional banks. Also, the imposition of ta'widh and gharamah by Bank Negara is in line with the Maqasid of Shari'ah (objectives of Islamic law) which it is important to protect the religion of Islam by ensuring the sustainability of Islamic banking.

Awang et al. (2017) discussed the benefits of the practice of charity where it will help banks to reduce the default risk further this proceeds will help the society Muneeza et al. (2019) investigated that the most significant reason behind the implementation of late payment charges in Malaysia was actually to mitigate the credit risk faced by the Islamic Financial Institutions.

Muscati (2007) examined the responses proposed regarding the issue of late payment in Islamic Banking. These responses include that; (1) any type of late payment fees to be a form of riba, (2) allowing debtors guilty of delinquency to be penalized, (3) allowing late fees whose proceeds are donated to charity, and (4) compensating actual damages suffered by the lender. The author then assesses whether such Islamic approaches to late payment offer a meaningful alternative to the conventional approaches. The author suggested changes that might help spur a new culture of Islamic finance that will revitalize and improve the competitiveness of the industry.

Abdullah (2018) investigated that the imposition of ta'wid has its justification if it was done based on the actual losses incurred by the bank or at the nominal amount for the sake of avoiding moral hazard among customers. In the event banks need to impose a penalty which is not based on the actual losses, then the proceeds should not be regarded as a bank's income. Instead, it should be channeled to charity organizations. In any case, banks need to evaluate the real 
position of the customer whether he/she is a genuine incapable debtor or just a negligent defaulter.

Omer and Hasan (2019) showed that these Islamic Banks adhere to the BNM rules and requirements with some minor differences in the implementation process. The findings would contribute positively in terms of enriching and contributing to the existing literature on the SNC practices by Islamic Banks, at the same time, establishing the levels of compliance of the banks under investigation.

The previous studies focused on the role of Shari'ah governance on the profitability of the Islamic banks but ignored the classification of the govern ance type based on its relationship to the charity proceeds. This study postulates that governance can be reactive where it is strict in finding the void transactions and penalizing the proceeds thus increasing the charity proceeds. On the other hand, it could proactively apply Sadd al dhara'i' methodology for closing doors on all new means to void transactions.

\section{Methods}

\subsection{Variables and Data Sources}

For the fulfillment of research objectives, table 3.1 enlists all the variables which are selected for the data analysis. The dependent variable is the total charity paid by the bank in natural log form. The Shari'ah governance-related variables include size, qualification of Islamic studies, qualification of Fiqh, reputation, and the expertise of the Shari'ah Supervisory Board (SSB); Whereas, the control variables include size, age and profitability of the banks. This study has included the full-fledged Islamic banks of Pakistan between 2008 and 2017.

Table 3.1: Variable Construction and Sources

\begin{tabular}{|l|l|l|}
\hline Name (Symbol) & Units & Source \\
\hline Charity Paid Annually (LCPA) & Natural log \% & $\begin{array}{l}\text { Annual Financial } \\
\text { Statements }\end{array}$ \\
\hline $\begin{array}{l}\text { Shari'ah Supervisory Board Size } \\
\text { (SSBSIZE) }\end{array}$ & \% of total & $\begin{array}{l}\text { Annual Financial } \\
\text { Statements }\end{array}$ \\
\hline $\begin{array}{l}\text { Shari'ah Supervisory Board with } \\
\text { Qualification of Islamic Studies } \\
\text { (SSBQ1) }\end{array}$ & \% of total & $\begin{array}{l}\text { Annual Financial } \\
\text { Statements }\end{array}$ \\
\hline $\begin{array}{l}\text { Shari'ah Supervisory Board with } \\
\text { Qualification of Fiqh (SSBQ2) }\end{array}$ & \% of total & $\begin{array}{l}\text { Annual Financial } \\
\text { Statements }\end{array}$ \\
\hline
\end{tabular}




\begin{tabular}{|l|l|l|}
\hline $\begin{array}{l}\text { Shari'ah Supervisory Board } \\
\text { Reputation of being member of } \\
\text { AAOIFI (SSBR) }\end{array}$ & \% of total & $\begin{array}{l}\text { Annual Financial } \\
\text { Statements }\end{array}$ \\
\hline $\begin{array}{l}\text { Shari'ah Supervisory Board with } \\
\text { Cross Membership (SSBCM) }\end{array}$ & \% of total & $\begin{array}{l}\text { Annual Financial } \\
\text { Statements }\end{array}$ \\
\hline $\begin{array}{l}\text { Shari'ah Supervisory Board } \\
\text { Expertise (SSBEX) }\end{array}$ & \% of total & $\begin{array}{l}\text { Annual Financial } \\
\text { Statements }\end{array}$ \\
\hline Size of Bank (SIZE) & $\begin{array}{l}\text { Natural log of } \\
\text { Total Assets }\end{array}$ & $\begin{array}{l}\text { Annual Financial } \\
\text { Statements }\end{array}$ \\
\hline Bank Age (AGE) & $\begin{array}{l}\text { Years since its } \\
\text { foundation }\end{array}$ & $\begin{array}{l}\text { Annual Financial } \\
\text { Statements }\end{array}$ \\
\hline Bank Profitability (ROA) & $\begin{array}{l}\text { Net income / } \\
\text { Total Assets }\end{array}$ & $\begin{array}{l}\text { Annual Financial } \\
\text { Statements }\end{array}$ \\
\hline
\end{tabular}

\subsection{Equation and Estimation Methods}

The units of this study are Islamic banks and time periods which make the data set spatial-temporal. Such data sets are better handled using panel data models. Following are the equations which this study will estimate to fulfill the research objectives.

$$
\begin{gathered}
\operatorname{lcpa}_{i t}=\alpha_{1}+\alpha_{2} \text { ssbsize }_{i t}+\alpha_{3} \text { size }_{i t}+\alpha_{4} a g e_{i t}+\alpha_{5} \text { roa }_{i t}+\varepsilon_{i t} \\
\text { lcpa }_{i t}=\alpha_{1}+\alpha_{2} s s b q 1_{i t}+\alpha_{3} \text { size }_{i t}+\alpha_{4} a g e_{i t}+\alpha_{5} \text { roa }_{i t}+\varepsilon_{i t} \\
\text { lcpa }_{i t}=\alpha_{1}+\alpha_{2} s s b q 2_{i t}+\alpha_{3} \text { size }_{i t}+\alpha_{4} a g e_{i t}+\alpha_{5} \text { roa }_{i t}+\varepsilon_{i t} \\
\text { lcpa }_{i t}=\alpha_{1}+\alpha_{2} \text { ssbr }_{i t}+\alpha_{3} \text { size }_{i t}+\alpha_{4} a g e_{i t}+\alpha_{5} \text { roa }_{i t}+\varepsilon_{i t} \\
\text { lcpa }_{i t}=\alpha_{1}+\alpha_{2} \text { ssbcm }_{i t}+\alpha_{3} \text { size }_{i t}+\alpha_{4} a g e_{i t}+\alpha_{5} \text { roa }_{i t}+\varepsilon_{i t} \\
\text { lcpa }_{i t}=\alpha_{1}+\alpha_{2} \text { ssbex }_{i t}+\alpha_{3} \text { size }_{i t}+\alpha_{4} a g e_{i t}+\alpha_{5} \text { roa }_{i t}+\varepsilon_{i t}
\end{gathered}
$$

This study has used Panel FGLS model to estimate the effects of different types of Shari'ah governance indicators on the total charity paid annually by the Islamic bank. The estimation methods are adapted from the studies like Hanif, Arshed \& Aziz, (2019); Hassan, Bukhari, \& Arshed, (2019); and Arshed \& Kalim, (2020).

\section{Results}

\subsection{Descriptive Statistics}

Table 2 provides descriptive statistics for the selected variables. Here we can observe that there are a few variables which are under dispersed as their mean value is higher than their standard deviation; these are LCPA, SSBSIZE, SSBCM, SIZE, and AGE. Some other variables including SSBQ1, SSBQ2, SSBR, SSBEX, 
Ayaz et al.

and ROA are over dispersed where the mean is smaller than the standard deviation.

Table 4.1: Decription Statistics

\begin{tabular}{|l|c|c|c|}
\hline Variable & Obs. & Mean & Std. Dev. \\
\hline LCPA & 51 & 9.138 & 1.607 \\
\hline SSBSIZE & 51 & 2.767 & 1.566 \\
\hline SSBQ1 & 51 & 0.121 & 0.149 \\
\hline SSBQ2 & 51 & 0.121 & 0.149 \\
\hline SSBR & 51 & 0.172 & 0.216 \\
\hline SSBCM & 51 & 0.493 & 0.299 \\
\hline SSBEX & 51 & 0.162 & 0.165 \\
\hline SIZE & 51 & 15.424 & 6.601 \\
\hline AGE & 51 & 9.850 & 7.385 \\
\hline ROA & 51 & 0.002 & 0.017 \\
\hline
\end{tabular}

\subsection{Graphical Analysis}

While comparing the graphical association, figure 4.1 shows that there is a positive association between the Shari'ah Supervisory Board Size and the charity paid by the Islamic banks indicating that with an increase in members of the board, there are more chances that they can detect the non-compliant transactions leading to an increase in the amount of charity.

The figure 4.2 shows that the increase in the proportion of Shari'ah board members who have Islamic study qualification leads to a decrease in the incidence of charity paid by the Islamic banks.

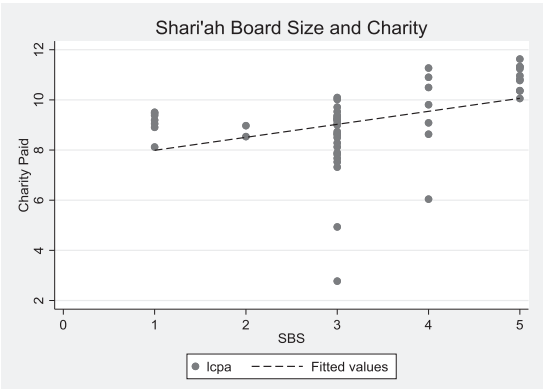

Figure 4.1: Association of Shari'ah Board Size and Charity

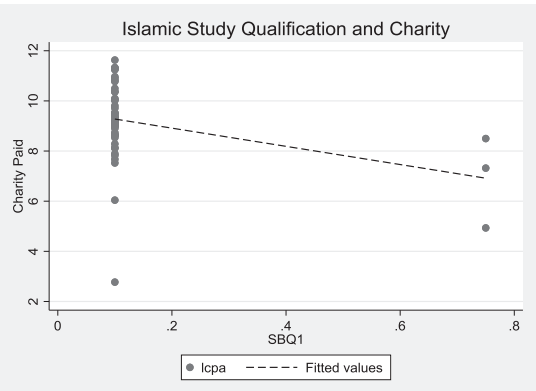

Figure 4.2 Association of Islamic Study Qualification and Charity

$\overline{\text { Vol. 5(2), 2020, pp. 77-91 }}$ 
Figure 4.3 shows a similar outcome as compared to figure 4.2 where an increase in the proportion of Shari'ah board who qualify Fiqh does lead to a decrease in the incidence of charity paid.

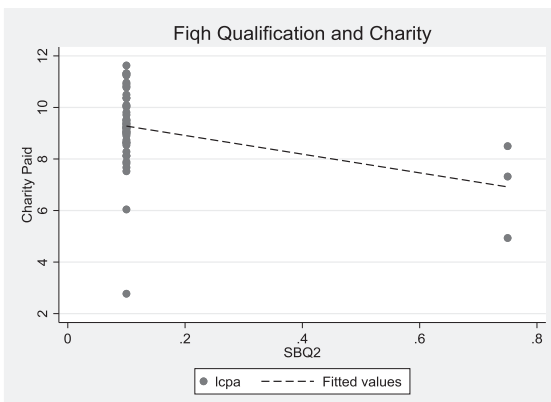

Figure 4.3: Association of Fiqh Qualification and Charity

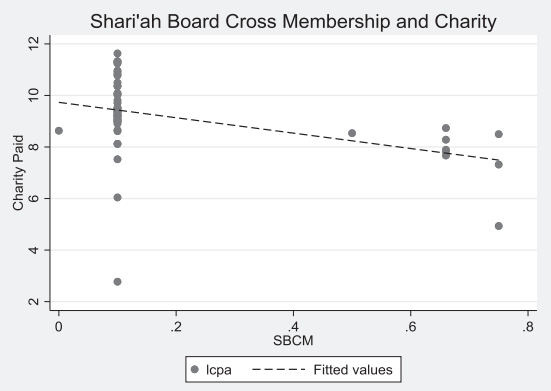

Figure 4.4: Association of Shari'ah Board Cross Membership and Charity

Figure 4.4 indicates that with the increase in the cross membership of Shari'ah board members, there is a decrease in the incidence of charity paid by the Islamic banks. This points to the fact that cross membership increases the experience from other banks which helps in closing the doors that lead to noncompliant outcome. Similar is the case with the experience and expertise of Shari'ah board members shown in figure 4.5.

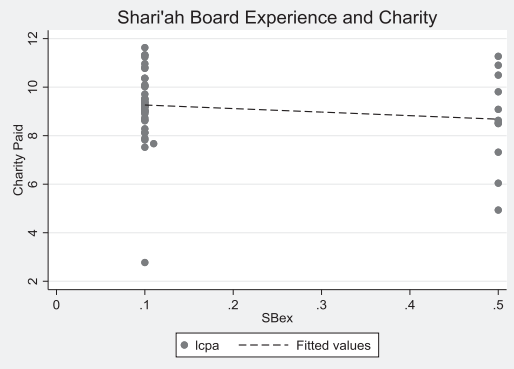

Figure 4.5: Association of Shari'ah Board Experience and Charity



Figure 4.6: Association of Shari'ah Board Reputation and Charity

Lastly, from figure 4.6, it becomes clear that with the increase in the reputation of the Shari'ah board, there is an increase in a charity paid by the Islamic banks. Assessing these graphs, it is observable that the effect of different 
characteristics of Shari'ah governance has a different association with charity collection. There is a need to estimate the effects of Shari'ah governance on charity collection so that the performance of the governance structure could be assessed (Hasan et al., 2020)

\subsection{Regression Estimates}

Table 3 reports the regression estimations of the model of Shari'ah governance and charity. Based on the significant value of the Wald test, it concludes that all the models are overall fit. While comparing the controlling variables it can be seen that an increase in the size of the Islamic bank reduces the charity paid by the banks. This is because an increase in size means an increase in the ability to regulate and formulate the transaction mechanisms which lead to fewer incidences of non- compliant transactions.

For the case of the age of the Islamic bank, the results indicate that with the increase in age, the banks are generally collecting a higher amount of charity. Whereas the profitability of the Islamic bank has no significant relationship with the charity paid.

While discussing the role of characteristics of Shari'ah supervisory board and the incidence of charity paid, following are observations. It can be seen that with an increase in the size of the Shari'ah Supervisory Board, there is an increase in the charity paid significantly. This shows that an increase in the size increases the ability to identify the non- compliant incidences. In contrast, an increase in other characteristics helps in reducing the charity by closing the doors of noncompliant activity.

This means that when bank increases its board size, there are more eyes to explore the void transactions which increase the sample to be covered by banks leading to an increase in charity proceeds. While an increase in the qualification in Islamic studies, fiqh and cross membership leads to a decrease in the charity paid by the bank. These indicators increase in the skill and efficiency of the board member to find the needle in the haystack. This makes them proactive, whereby they place efforts in mitigating all Sadd al dhara' $i$ ' with their experience and clarifying their duties (Grassa, 2015). A study by Hanif and Arshed (2016) pointed out that these indicators of Shari'ah governance have a positive effect on the earnings of the banks. This study provides the reasoning for an increase in earning by restricting the charity being deducted from the bank's earnings and forming strict controls. 
COMSATS Journal of Islamic Finance

Table 4.2: Regression Estimations

\begin{tabular}{|c|c|c|c|c|c|c|}
\hline \multicolumn{7}{|c|}{ Panel FGLS Estimates } \\
\hline $\begin{array}{l}\text { Variab } \\
\text { les }\end{array}$ & $\begin{array}{l}\text { Coef. } \\
\text { (Prob.) }\end{array}$ & $\begin{array}{l}\text { Coef. } \\
\text { (Prob.) }\end{array}$ & $\begin{array}{l}\text { Coef. } \\
\text { (Prob.) }\end{array}$ & $\begin{array}{l}\text { Coef. } \\
\text { (Prob.) }\end{array}$ & $\begin{array}{l}\text { Coef. } \\
\text { (Prob.) }\end{array}$ & $\begin{array}{l}\text { Coef. } \\
\text { (Prob.) }\end{array}$ \\
\hline $\begin{array}{l}\text { SSBsiz } \\
\text { e }\end{array}$ & $\begin{array}{l}0.549 \\
(0.04)\end{array}$ & & & & & \\
\hline SSBq1 & & $\begin{array}{c}- \\
3.701(0.0 \\
2)\end{array}$ & & & & \\
\hline SSBq2 & & & $\begin{array}{c}- \\
3.701(0.0 \\
2)\end{array}$ & & & \\
\hline $\mathrm{SSBcm}$ & & & & $\begin{array}{c}- \\
1.932(0.0 \\
0)\end{array}$ & & \\
\hline $\mathrm{SSBr}$ & & & & & $\begin{array}{c}1.139(0.3 \\
2)\end{array}$ & \\
\hline SSBEx & & & & & & $\begin{array}{c}0.389(0.7 \\
7)\end{array}$ \\
\hline Size & $\begin{array}{l}-0.767 \\
(0.00)\end{array}$ & $\begin{array}{c}- \\
0.477(0.0 \\
0)\end{array}$ & $\begin{array}{c}- \\
0.477(0.0 \\
0)\end{array}$ & $\begin{array}{c}- \\
0.366(0.0 \\
3)\end{array}$ & $\begin{array}{c}- \\
0.926(0.0 \\
0)\end{array}$ & $\begin{array}{c}- \\
0.962(0.0 \\
0)\end{array}$ \\
\hline Age & $\begin{array}{l}0.059 \\
(0.23)\end{array}$ & $\begin{array}{c}0.141(0.0 \\
0)\end{array}$ & $\begin{array}{c}0.141(0.0 \\
0)\end{array}$ & $\begin{array}{c}0.116(0.0 \\
0)\end{array}$ & $\begin{array}{c}0.116(0.0 \\
0)\end{array}$ & $\begin{array}{c}0.139(0.0 \\
0)\end{array}$ \\
\hline ROA & $\begin{array}{c}- \\
13.135(0 . \\
27)\end{array}$ & $\begin{array}{c}- \\
4.637(0.3 \\
6)\end{array}$ & $\begin{array}{c}- \\
4.637(0.3 \\
6) \\
\end{array}$ & $\begin{array}{c}- \\
1.403(0.7 \\
7) \\
\end{array}$ & $\begin{array}{c}- \\
7.368(0.5 \\
4) \\
\end{array}$ & $\begin{array}{c}- \\
1.831(0.8 \\
6) \\
\end{array}$ \\
\hline $\begin{array}{l}\text { Consta } \\
\mathrm{nt}\end{array}$ & $\begin{array}{c}20.662(0 . \\
00)\end{array}$ & $\begin{array}{c}16.722(0 . \\
00)\end{array}$ & $\begin{array}{c}16.722(0 . \\
00)\end{array}$ & $\begin{array}{c}15.039(0 . \\
00)\end{array}$ & $\begin{array}{c}23.992(0 . \\
00)\end{array}$ & $\begin{array}{c}24.984(0 . \\
00)\end{array}$ \\
\hline \multicolumn{7}{|c|}{ Regression statistics } \\
\hline Obs & 51 & 51 & 51 & 51 & 51 & 51 \\
\hline $\begin{array}{l}\text { Wald } \\
\text { (prob.) }\end{array}$ & $\begin{array}{l}26.71 \\
(0.00)\end{array}$ & $\begin{array}{l}75.05 \\
(0.00)\end{array}$ & $\begin{array}{l}75.05 \\
(0.00)\end{array}$ & $\begin{array}{l}81.34 \\
(0.00)\end{array}$ & $\begin{array}{l}22.42 \\
(0.00)\end{array}$ & $\begin{array}{l}21.14 \\
(0.00)\end{array}$ \\
\hline
\end{tabular}

\section{Conclusions and Policy Implications}

The merits of Shari'ah governance on the performance of Islamic banks is a wellknown phenomenon in literature. The present study opens a new venture to 
explore the role of Shari'ah governance in ability to find non-compliant income. The idea behind it is the concept of hisba and justice. According to hisba rule, Shari'ah board will close doors to all known non-compliant transactions thus leading to reduction in the collection of charity. While according to justice rule, Shari'ah board will not excuse any non-compliant transaction thus leading to an increase in the collection of charity. Even though charity is suitable for the society, but this charity does not help banks in their day to day Shari'ah compliant functions.

This study has collected data of Islamic Banks of Pakistan between 2008 to 20017. Six indicators of Shari'ah governance are collected from the financial statements. Using panel FGLS estimates, the results indicate that increase in the Shari'ah board increases the justice ability of the Shari'ah governance; whereas, increase in the skills of Islamic studies and Fiqh studies and the cross-board membership leads to increase in the hisba ability of the Shari'ah governance.

This study proposes that Shari'ah Supervisory Board should focus on the qualification and cross board membership of the Shari'ah scholars rather than increase in the Shari'ah board size. In this way, there will be a gradual decrease in the collection of charity by the banks. This study proposes that the Fiqh and Islamic studies knowledge is most effective in reducing future charity deduction from the income of the bank, hence the smooth functionality of bank requires human capital development of Shari'ah board in terms of Fiqh and Islamic studies. Educational institutes must develop rigorous curricula that can impart skill development among the masses and specially Shari'ah board members.

\section{References}

Abdullah, A. (2018). Late Payment Treatment in Islamic Banking Institutions in Malaysia: A Maqasid Analysis. International Journal of Academic Research in Business and Social Sciences, 8(11), 30-43.

Alam, M. K., Ab Rahman, S., Mustafa, H., Shah, S. M., \& Hossain, M. S. (2019). Shariah governance framework of Islamic banks in Bangladesh: Practices, problems and recommendations. Asian Economic and Financial Review, 9(1), 118-132

Alaswad, S. A. M., \& Stanišić, M. (2016). Role of internal audit in performance of

Libyan financial organizations. International Journal of Applied Research, 2(2), 352-356.

Al-Suyuti Al-Asybah wa al-Naza'ir, Dar Al-Kutub Al-'Ilmiyyah. [83-84]. Alnasser, S. A. S., \& Muhammed, J. (2012). Introduction to corporate governance from Islamic perspective. Humanomics, 28(3), 220-231. 
Arshed, N., \& Kalim, N. (2020). Modelling demand and supply of Islamic banking deposits. International Journal of Finance $\mathcal{E}$ Economics. Early view. https://doi.org/10.1002/ijfe.1936

Ayaz, M., Jamal, K. F., Shaheen, S., \& Arshed, N. (2020). Sources and uses of charity fund accounts: A comparative analysis of Islamic banks in Pakistan. COMSATS Journal of Islamic Finance, 5(1), 14-40

Awang, S. A., Muhammad, F., Borhan, J. T., \& Mohamad, M. T. (2017). The Concept of Charity in Islam: An Analysis on the Verses of Quran and Hadith. Jurnal Usuluddin, 45(1), 141-172.

Awdat, A. A. (2015). The impact of the internal audit function to improve the financial performance of commercial banks in Jordan. Research Journal of Finance and Accounting, 6(3), 217-225.

Bahari, N. F., \& Baharudin, N. A. (2016). Shariah Governance Framework: The Roles of Shariah Review and Shariah Auditing. In Proceeding of the 3rd International Conference on Management \& Muamalah 2016 (3rd ICoMM) (pp. 375-382)

Chik, M. N. (2011, May). Shariah audit: Shariah perspective. In International Shariah Audit Conference (p. 2011).

Ginena, K. (2014). Shar'̄'ah risk and corporate governance of Islamic banks. Corporate Governance, 14(1), 86-103. https://doi.org/10.1108/CG03-2013-0038

Garas, S. N., \& Pierce, C. (2009). Shari'a supervision of Islamic financial institutions, (Appendix 1). https://doi.org/10.1108/13581981011093695

Grassa, R. (2015). Shariah supervisory systems in Islamic finance institutions across the OIC member countries. Journal of Financial Regulation and Compliance, 23(2), 135-160

Hanif, N., \& Arshed, N. (2016). Comparison of Disclosure Level among Islamic Banks and Its Effect on Performance. Islamic Banking and Finance Review (IBFR), 3(1), 44-66.

Hanif, N., Arshed, N., \& Aziz, O. (2019). On interaction of the energy: Human capital Kuznets curve? A case for technology innovation. Environment, Development and Sustainability, 1-28.

Hasan, A. N., Abdul-Rahman, A., \& Yazid, Z. (2020). Shariah governance practices at Islamic fund management companies. Journal of Islamic Accounting and Business Research, 11(2), 309-325

Hassan, M. S., Bukhari, S., \& Arshed, N. (2019). Competitiveness, governance and globalization: What matters for poverty alleviation?. Environment, Development and Sustainability, 1-28. 
Hassan, M., Rizwan, M., \& Sohail, H. M. (2017). Corporate governance, Shariah advisory boards and Islamic banks' performance. Pakistan Journal of Islamic Research, 18(1), 173-184.

Iqbal, Z., \& Mirakhor, A. (2004). The development of Islamic financial institutions and future challenges. Islamic Finance: Innovation and Growth. London: Euromoney Books.

Muneeza, A., Zainudin, N. A., Ali, R., Ibrahim, S. N., \& Mustapha, Z. (2019). Application of Ta'widh and Gharamah in Islamic Banking in Malaysia. The Journal of Muamalat and Islamic Finance Research, 1-16.

Muscati, S. A. (2006). Late Payment in Islamic Finance. UCLA Journal of Islamic $\mathcal{E}$ Near Eastern Law (JINEL), 6, 47.

Mollah, S., \& Zaman, M. (2015). Shari'ah supervision, corporate governance and performance: Conventional vs. Islamic banks. Journal of Banking $\mathcal{E}$ Finance, 58(August 2016), 418-435. https://doi.org/10.1016/j.jbankfin.2015.04.030

Musibah, A. S. (2014). The Mediating Effect of Financial Performance on the Relationship between Shariah Supervisory Board Effectiveness, Intellectual Capital, (August). https://doi.org/10.5539/ass.v10n17p139

Nawaz, T. (2017). Intellectual capital, financial crisis and performance of Islamic banks: Does Shariah governance matter?. Available at https://pearl.plymouth.ac.uk/bitstream/handle/10026.1/10766/Institutional \%20Repository.pdf?sequence $=1 \&$ isAllowed $=y$

Omar, H. N., \& Hassan, R. (2019). Shariah Non-Compliance Treatment in Malaysian Islamic Banks. International Journal of Management and Applied Research, 6(4), 218-231.

Siddiqi, A.H. (1999). Sahih Muslim; Arabic-English (India: Adam Publishers \& Distributors., 1999), 2:91.

Shahruddin, M. S., Yazid, N. H. M., Tesl, U. T., \& Alam, S. (2013). Late Payment Charge in Islamic Bank. Islamic Finance: Challenges of Islamic Banking in Pakistan. Available at http://mak.trunojoyo.ac.id/wpcontent/uploads/2014/04/P35_Late-Payment-Charge-in-IslamicBank_Ezani1.pdf

Yaakub, E., Adil, M. A. M., Husin, A., Muhamad, M. D., Khalid, M. M., \& Shahruddin, M. S. (2014). A Revisit to the Practice of Late Payment Charges by Islamic Banks in Malaysia. Jurnal Pengurusan, 4, 185 - 190

Zulkipli, Z. N. B. (2019). Late Payment Penalty: Ta'widh And Gharamah Imposed To Debtor From The Shariah Perspective. Yuridika, 35(1), 187-210.

Zain, S. N. M., \& Shafii, Z. (2018). The impact of Shariah governance to financial and non-financial performance in Islamic financial institutions (IFIs): $\mathrm{A}$ literature survey. International Journal, 3(2), 27-40. 